\title{
The Krebet Tourism Village Development in the Industry 4.0 Era
}

\author{
Desy Nur Aini Fajri ${ }^{1}$
}

\author{
Affiliation \\ ${ }^{1}$ International Relations Department, Universitas Pembangunan Nasional "Veteran" \\ Yogyakarta.
}

\section{Correspondence}

Desy Nur Aini Fajri. Department of International Relations, Faculty of Social and Political Science, Universitas Pembangunan Nasional "Veteran" Yogyakarta. JL. Babarsari, No. 2, Tambak Bayan, Daerah Istimewa Yogyakarta.Email: desy.nur@upnyk.ac.id.

\begin{abstract}
The purpose of this study is to explore further how the tourism system of the Krebet Tourism Village in the Industrial Era 4.0. In developing a sustainable tourism village, there must be a tourism system developed to take advantage of opportunities in the Ind ustry 4.0 Era. This study uses a descriptive qualitative research modeland in-depth interviews conducted with villager and the local government. The Bantul Rege ncy Government is developing the Krebet Tourism Village so that it can help encourage the growth of the tourism industry in the Province of DIY. Each tourism destination will be influenced by the tourism system which consists of main components that are interrelated in a close and influential relationship. The Gunn Model in the Tourism System - supply and demand c an analyze in detail how the tourism system develops the Krebet Tourism Village. The results is to satisfy market demand (Krebet Tourism Village) must be able to provide services and a variety of development (supply) which includes Attractions, Promotions, Information, Services, and Transportation. Besides, the success of the tourism syste $\mathrm{m}$ in the Krebet Village is also influenced by external factors including (1) natural resources; (2) cultural resources; (3) organization/ leadership; (4) financial; (5) labor; (6) entrepreneur ship; (7) community; (8) competition; (9) government policies. That is why the Tourism Village must take advantage of opportunities in the industrial era 4.0 by building a good tou r is $m$ system.
\end{abstract}

Keywords: Tourism System; Tourism Village; Industrial Era 4.0; Demand Sides; Supply Sides.

\section{Article Information}

Submitted 27 April 2020 | Revised 25 September 2020 | Accepted 28 January 2021

Recommended Citation: Fajri, D. N. A. (2020). The Krebet Tourism Village Development in the Industry 4.0 Era. Jurnal Pariwisata Terapan , 4(2), 92-110.

https://dx.doi.org/10.22146/jpt.55686

Copyright (C) 2020 bythe author(s). This artide is published by Universitas Gadjah Mada, Indonesia under the Creative Commons Attribution (CC BY 4.0) license. Anyone may reproduce, distribute, translate, and create derivative works of this article (for both commercial and noncommercial purposes), subject to full attribution to the original publication and author(s). The full terms of this license may be seen at http://creativecommons.org/licenses/by/4.0/legalcod 


\section{Introduction}

The tourism industry has shown rapid development and can provide a multiplier effect, especially on local communities. One form of application of sustainable tourism based on the community is through the development of a Tourism Village. Shifting the international tourist market segment from mass tourism to special interest tourism, changing tourist tastes, and increasing the ability to travel has pushed the Tourism Village to become a major base for creative economic development. Tourism Village was chosen as an alternative to tourism development because Tourism Village is closer to the community as the main behavioral component (Purbasari and Manaf, 2017). Thus, the Tourism Village can be an alternative destination for tourists to get a tour experience through learning local culture and enriching their insights while maintaining environmental elements. This has created a new phenomenon in the development of infrastructure and various other facilities, which are used by tourists (Rojek \& Urry, 1997; Desmond, 1999; Gottdiener, 2000; Urry, 2002). As a tourist destination, it must have at least five important elements, namely attractions, facilities, infrastructure, transportation, and hospitality (Spillane, 1994).

The Special Province of Yogyakarta (DIY) has considerable Tourism Village potential and is very well developed to capture the opportunities of new tourist market segments. A tourist destination needs to be managed according to changing tastes, needs, and desires of tourists (Jawardena, 2002). Therefore, a tourist destination must be more creative and unique and have a strong branding that is oriented towards tourists. the Yogyakarta Provincial Tourism Office has carried the "Jogja Cultural Experiences" motto that provides cultural experiences to tourists and as a strategy to strengthen brand destinations to increase the attractiveness of DIY tourism. At present, DIY Province has 114 Tourism Villages with 119 Tourism Awareness Groups (Pokdarwis), has more than 200 homestays and it is is not capitalist but developed from the community (Raharjo, 2019). The concept of live-in in the Tourism Village is khitah, not replicating elsewhere. The most important thing is the strength of the local culture (point of differences). That is, shows and activities in a Tourism Village are not found in other Tourism Villages and have a new concept offered. So, the more unique a destination, the more attractive it is for tourists.

One of the Tourism Villages that is unique in the Province of DIY is the Krebet Tourism Village with its characteristic wooden batik crafts. This village is located in Sendangsari Village, Pajangan District, Bantul Regency, DIY Province. Crafts are a chain of the tourism industry where the Tourism Village is used as its base. In its development, the Government of Bantul Regency is based on the Bantul Regency Regulation Number 18 the Year 2015 Regarding the Regional Tourism Development Master Plan (RIPPDA) for 2015 - 2025 concerning the direction of the Development of Regional Tourism Strategic Areas. In it explained the elaboration of 44 Regional Tourism Development Areas (KPPD) in 9 Regional Tourism Strategic Areas (KSPD) and 5 Regional Tourism Destinations (DPD). The development of the Krebet Tourism Village is included in the Krebet-Selarong-Pandak KSPD and the Pangeran Diponegoro DPD. 


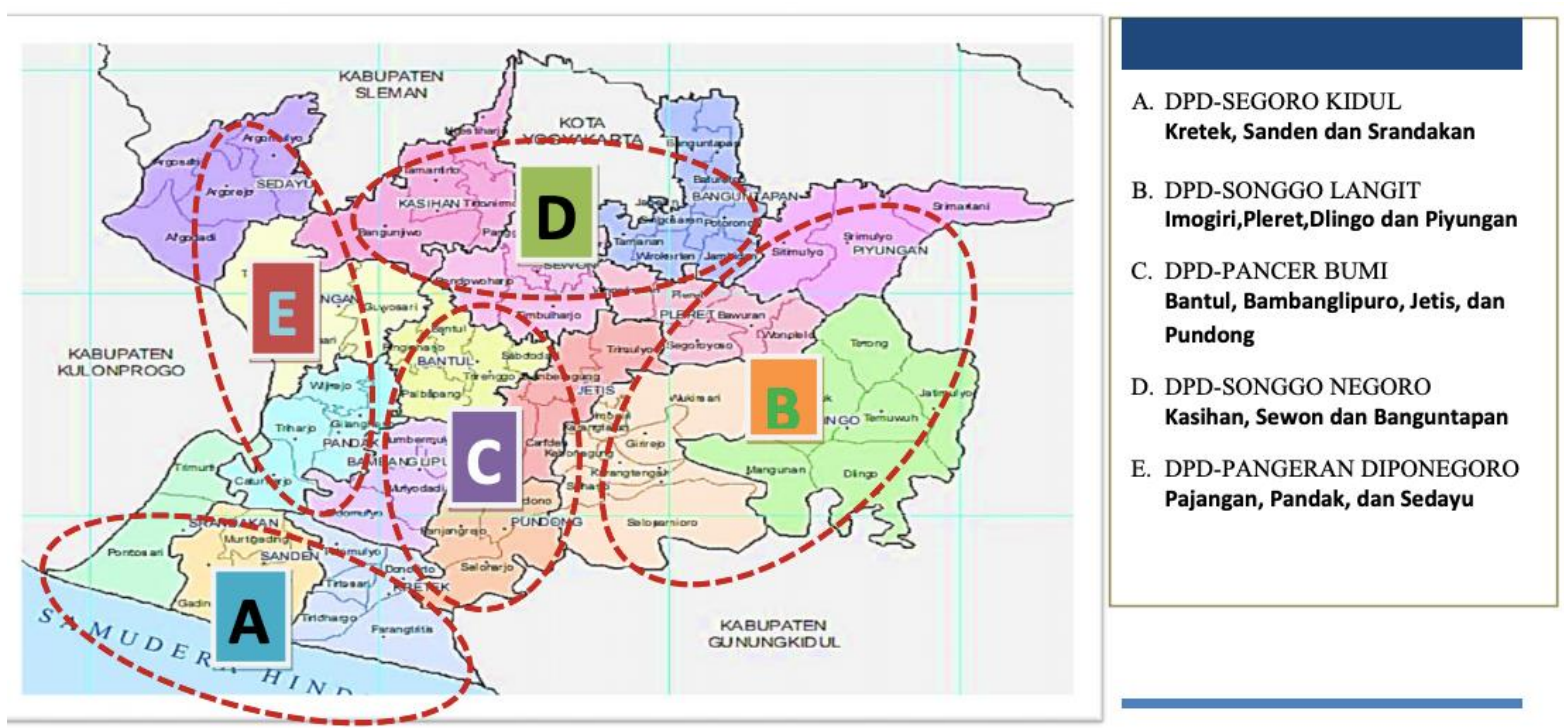

Figure 1. Regional Map of the Development of the Five Tourism Destinations in the Bantul Regency in the 2015-2025 RIPPDA

Source: Bantul Regency Government, 2015

Bantul Regency area is very good to be developed because in it there are potential superior products that can raise the welfare of the community, including its craft. Bantul Regency has 38 Tourism Villages, 10 Tourism Villages are categorized as healthy in the sense that the Tourism Village visit increases with broad community participation (Prabowo, 2019). Meanwhile, the remaining 28 Tourism Villages are still not optimal. Krebet is included in the healthy category and has become an Independent Tourism Village. Therefore, the Krebet Tourism Village was developed by the Bantul Government to help encourage the growth of the tourism industry in DIY. The wooden batik became an icon and also became the economic backbone of the citizens. The products produced by craftsmen are all forms made from wood and then made into souvenirs, wooden batik masks, wayang klitik, tissue boxes, trays, and all other functional forms. The Krebet wood batik products are not only marketed domestically such as Bali, Jakarta, and Surabaya but also have penetrated global markets such as India, Malaysia, Singapore, countries in Europe, and other countries. Every month Krebet can produce 10,000 to 20,000 items of wooden batik handicraft products, with a turnover of about Rp. 25-40 million per month. The average tourist arrivals are 500 people per month and shopping guests as much as 20,000 per year (Agus Jati Kumara, Personal Communication, 29 September 2019). Still, according to Agus Jati Kumara, the travel agency involved in the Krebet Tourism Village not only came from Yogyakarta but also from cities such as Bandung and Jakarta. In terms of tourist arrivals, the Krebet Tourism Village continues to increase from year to year. So, do not be surprised if many tourists who come because they are interested in local superior products. The Krebet Tourism Village also won 1st place in the Province / Yogyakarta Tourism Competition in 2019. Therefore, the Krebet Tourism Village continues to develop attractive attractions, accessibility, amenities/facilities to attract tourists visiting (the supply sides).

The condition of the development of the Krebet Tourism Village is different from other Handicraft Tourism Villages, such as the Bobung Tourism Village, which both produce wooden batik as their superior product. Bobung Tourism Village is located in Putat Village, Patuk District, Gunungkidul Regency. The government of Gunungkidul Regency began 
developing the Bobung Village as a pioneer of the Cultural Village in 2002. Then, the Bobung Village was designated as a Tourism Village in 2005. Most of the Bobung Tourism Village residents work as wooden batik craftsmen for generations, the cultural potential of Klana Dance Mask, and celebration of the Rasulan tradition. Bobung Village has 19 craft studios, or not as many as Krebet Tourism Village. The biggest handicraft studio is Sanggar Karya Manunggal with an average turnover of Rp. 30 million per month. However, not all handicraft studios get the same amount of turnover as Sanggar Karya Manunggal. Tourist visits that stay at the Bobung Tourism Village homestay are still minimal even though this Tourism Village has been developed for a long time. According to Kardiman, most of the Bobung community only focused on the wooden batik sector because it was considered more profitable. Supposedly, the basic concept of utilizing regional potential is a step to improve the welfare of the population in rural areas (Baiquni, 2006). If all aspects are developed in a good tour and marketing package it will certainly provide a special attraction for people who visit and will provide benefits for the welfare of the local community.

Krebet Tourism Village and Bobung Tourism Village both have superior products, namely wooden batik crafts, but differ in their development. Krebet's independence can be shown from not only being able to produce wooden batik on a large scale and increasing tourist visits but also by effective marketing by developing its own creativity. One of them is by using technology and information through the internet. Many studios and groups of craftsmen in the Krebet Tourism Village have been able to sell online. Thus, Krebet's superior products are known not only in the national market but also in the global market. Tourism Village is the life of the people who are almost 50 percent dependent on tourism. According to Usmar Salam (2011) states that a good tourist village is a village where every day there are tourists who come, produce souvenirs or other crafts. So, it can be said that the Krebet Tourism Village is more ready to accept tourists and can follow market trends (demand sides) compared to the Bobung Tourism Village.

To clarify the development of the two Tourism Villages, the following will be explained the comparison between Krebet Tourism Village and Bobung Tourism Village:

Table. 1. Comparison of the Development of Krebet Tourism Village and Bobung Tourism Village

\begin{tabular}{|c|c|c|c|}
\hline No & Category & Krebet Tourism Village & Bobung Tourism Village \\
\hline 1 & Spesification & Wooden batik craft & Wooden batik craft \\
\hline 2 & Location & $\begin{array}{l}\text { Sendangsari Village, Pajangan, } \\
\text { Bantul Regency }\end{array}$ & Putat Village, Patuk, Gunung Kidul Regency \\
\hline 3 & Accessibility & $\begin{array}{l}\text { Approximately } 12 \mathrm{~km} \\
\text { Southwest of Yogyakarta City. } \\
\text { There are } 2 \text { alternative roads, } \\
\text { namely passing: } \\
\text { 1. Kasongan Tourism Village } \\
\text { Road or } \\
\text { 2. Turn right after reaching the } \\
\text { Great Mosque of Bantul } \\
\text { (approximately } 6 \mathrm{~km} \text { ) } \\
\text { Visitors must prepare a private } \\
\text { vehicle or contact a tour agent } \\
\text { that provides services because }\end{array}$ & $\begin{array}{l}\text { About } 500 \text { m from the main road Jogja-Wonosari. } \\
\text { There are } 2 \text { roads to Bobung, namely: } \\
\text { 1. Closer but in certain locations damaged, there } \\
\text { are no motorcycle/ public tran portation. } \\
\text { 2. Farther, but the road is easier to pass. } \\
\text { There is public transportation such as city buses, } \\
\text { only from the main road to Bobung it is difficult to } \\
\text { find transportation, onlymotorcycle (ojek). }\end{array}$ \\
\hline
\end{tabular}




\begin{tabular}{|c|c|c|c|}
\hline & & $\begin{array}{l}\text { there is no public } \\
\text { transportation reaching the } \\
\text { Krebet location. }\end{array}$ & \\
\hline 4 & Market & $\begin{array}{l}\text { On average, each handicraft } \\
\text { business ownercan geta } \\
\text { turnover of Rp. } 25-40 \text { million } \\
\text { per month. }\end{array}$ & $\begin{array}{l}\text { The biggest handicraft business owner is Rp. } 30 \\
\text { million every month, other craft owners are still } \\
\text { limited. }\end{array}$ \\
\hline 5 & $\begin{array}{l}\text { Tourist Arrivals } \\
\text { (2019) }\end{array}$ & $\begin{array}{l}\text { Tourist arrivals increase every } \\
\text { year. } \\
\text { An average of } 500 \text { tourists per } \\
\text { month. Shopping tourism } \\
20,000 \text { tourists/ year. }\end{array}$ & Tourist Arrivals have not fully stable. \\
\hline 6 & $\begin{array}{l}\text { The number of } \\
\text { wooden batik } \\
\text { business owners } \\
\text { (2019) }\end{array}$ & $\begin{array}{l}57 \text { wooden batik business } \\
\text { owners. }\end{array}$ & 19 wooden batik business owners. \\
\hline 7 & $\begin{array}{l}\text { The number of } \\
\text { homestays } \\
(2019)\end{array}$ & $\begin{array}{l}25 \text { homestays ( } 80 \text { rooms), } \\
\text { capacity } 300 \text { people. }\end{array}$ & The capacity of 120 people. \\
\hline 8 & $\begin{array}{l}\text { The number of } \\
\text { art group }\end{array}$ & $\begin{array}{l}9 \text { art groups. } \\
\text { For dances, routine activities } \\
\text { are held once a week. }\end{array}$ & 1 art group. \\
\hline 9 & Achievement & $\begin{array}{l}\text { 1. Champion } 1 \text { Village/Tourism } \\
\text { Village } 2019 \text { DIY Level. } \\
\text { 2. Often wins musical } \\
\text { competition at the provincial } \\
\text { level DIY. } \\
\text { 3. MURI recordin making the } \\
\text { biggest mask. }\end{array}$ & $\begin{array}{l}\text { It was established by the Gunung Kidul Regency } \\
\text { Government as a pioneer of the Cultural Village in } \\
2002 \text { and became a Tourism Village in } 2005 .\end{array}$ \\
\hline 10 & $\begin{array}{l}\text { Promotion } \\
\text { (internet) }\end{array}$ & $\begin{array}{l}\text { Krebet already has its website, } \\
\text { even able to sell products } \\
\text { online through } \\
\text { www.krebet.com }\end{array}$ & $\begin{array}{l}\text { Already have a we bsite but not up to date, } \\
\text { namely: } \\
\text { www.bobungdesawisata.blogspot.co.id } \\
\text { www.wisata.gunungkidulkab.go.id } \\
\text { Bobung has not been able to sell online. }\end{array}$ \\
\hline
\end{tabular}

Source: Data from Krebet Tourism Village and Bobung Tourism Village, 2019

In the description Table 1. above it can be said that the Krebet Tourism Village is more ready, independent, and more sustainable than the Bobung Tourism Village. Certainly, in the development of a Tourism Village, it cannot be separated from how the tourism system in an area, in this case, Tourism Village. Each tourism destination will be influenced by the tourism system which consists of main components that are interrelated in a close and influential relationship. The match between demand sides and supply sides is the key to success in tourism development (Gunn, 2002). Gunn stressed to satisfy market demand (demand), an area must provide services and a variety of development (supply). Then, Gunn also added that the success of the tourism system was also influenced by external factors including (1) natural resources; (2) cultural resources; (3) organization/leadership; (4) financial; (5) labor; (6) entrepreneurship; (7) community; (8) competition; (9) government policies (Gunn, 2002).

This paper tries to explain how the tourism system in the development of the Krebet Tourism Village in the industri 4.0 era so that the Krebet Tourism Village is more sustainable than the Bobung Tourism Village. 


\section{Tourism Village Definition}

Tourism Village is where small groups of tourists stay in or near traditional, often remote villages and learn about village life and the local environment (Inskeep, 1991). Furthermore, Tourism Village as a form of integration between attractions, accommodation and supporting facilities that are presented in a community life structure that integrates with applicable procedures and traditions (Nuryanti, 1993). Based on Nuryanti's definition, there are two main concepts in the Tourism Village namely Accommodation and Attractions. Accommodation is part of the residential units that are developed based on the concept of residence. Meanwhile, Attractions are all the daily lives of local community along with the physical setting of the village location that allows integration of tourists as active participation such as: learning to dance, craft, languages, and others that are specific.

So, it can be interpreted that the tourism village is a rural environment often in remote villages where there is a group of tourists who can learn about local life or culture and also the environment traditionally attractions accompanied by accommodation and other supporting facilities.

Tourism Village Definition from (United Nations Development Program and the World Tourism Organization, 1981), there are several basic principles in the development of Tourism Villages, including:

1. Development of tourism facilities on a small scale and their services in or near villages.

2. These facilities and services are owned and carried out by villagers and one of them can work with individuals who have these facilities.

3. The development of a tourism village can be based on one of the traditional cultural characteristics inherent in a village or the characteristics of attractions that are close to nature, with the development of the village as a service center visiting both attractions.

Tourism Village Definition (Center of Tourism Studies UGM, 2000), several aspects need to be considered in developing a Tourism Village, including:

1. Aspects of Tourism Village Management. Good and adequate management is needed namely transparent management. For example, there is a crisis of trust in managers, so as not to develop into issues that can hamper the progress of the Tourism Village.

2. Aspects of tourism village products: attractions include learning activities of village crafts, village arts, paddy field activities (plantations), sports activities (outbound), traditional ceremonies, meditation rituals, house construction, etc. Traditional dishes both on menu and method; accommodation, in this case, is characteristic of local accommodation, modifying local houses with local architecture.

3. Aspects of the tourist market: paying attention to the types of tourists namely individual, educated, prefer learning experience, learning from experience, middle class economic status, like cultural interaction with the local community. Also worth noting are the product quality standards, product diversification offered and the active involvement of tourists. 
4. Aspects of attraction management: the development of a tourism village needs a strong foundation, there is an awareness to play an active role in developing the village into a tourism village that can prosper.

The Krebet Tourism Village is a special interest tourist destination visited by tourists to gain experience through learning art, culture, and integration with Krebet life, events, and customs, supported by attractions, accommodations, and facilities as products managed and offered by the local community. The tourism system has an important role in developing tourist-friendly destinations (Anuar., et.al., 2012). The tourism system of the Krebet Tourism Village is inseparable from the main functions of supply and demand as will be explained using Gunn's Model analysis in the Tourism System.

\section{Gunn's Model Analysis in Tourism System - Supply and Demand in the Development of the Krebet Tourism Village}

Gunn's Model is an alternative model developed (Mill \& Morrison, 1985) and Leiper (Leiper, 1989) which is a tourism system model that emphasizes the dimensions of supply and demand. The Gunn model focuses on the importance of experiences gained by tourists. Tourism has elements that are closely related and related to one another. The tourism system consists of the demand side and the supply side of tourists such as transportation, attractions, facilities, services, information, and promotion of the trips offered (Gunn, 1988; 1994; Leiper, 1989). Gunn states that there are three basic things in tourism planning, namely, First, all regions must develop tourism planning following their frameworks in politics and ideology. Second, tourism planning must consider the basic functions that influence each other between supply and demand in a tourism system. Third, the basic function of the tourism system is influenced by external factors, namely cultural resources (natural resources), natural resources (natural resources), government policy (government policy), competition (competition), community (community), entrepreneurship (entrepreneurship), labor (labor), finance (finance) and organization/leadership (organization/leadership) (Rindrasih, 2015).

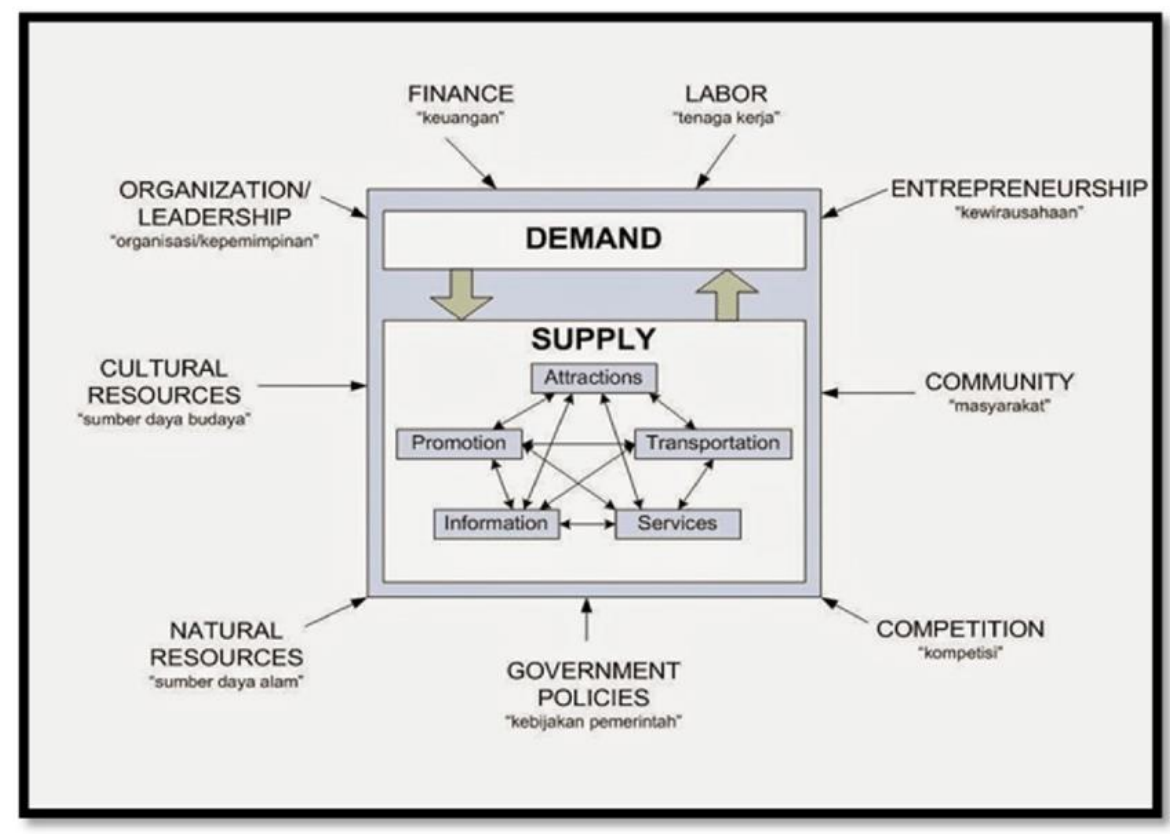

Figure 2. Gunn's Model Tourism System (1972) Economic Dimensions Source: Modified from Gunn, 2002 in Tourism System - supply and demand 
Figure 2. above shows that the tourism system has interrelated components. Destination is a travel marketing (Gunn, 1994). In the case of Krebet, the demand and supply sides are very important in the development of the Krebet Tourism Village. The tourism system consists of elements of accommodation, promotion, attractions, transportation, and visitors (Mason, 2003; Middleton, 1994; Leiper, 1990).

\section{Research Method}

In September 2019, the author visited Bantul Regency, DIY Province in the context of research data collection. This study uses a descriptive qualitative research model and in depth interviews conducted with villager and local government. The purpose of this visit is the author can be given information about tourism activities and systems, especially Krebet Tourism Village. Research data collection was carried out by interviewing manager of the Krebet Tourism Village and the Local Government, namely the Bantul Regency Tourism Office. The author believes that the informants involved in this study can be a representation of the Krebet Tourism Village community so that the information obtained can represent factual conditions. The research data was also obtained by making direct observations to the Krebet Tourism Village specifically relating to the physical conditions, facilities, and village environment. In collecting data, the authors utilize the strategy of recording an interview and observation data.

\section{Results and Discussion}

\section{Krebet Tourism Village}

Krebet Tourism Village is located in the Sendangsari Village, Pajangan Sub District, Bantul Regency. It is located in the west of Bantul Regencywith a distance of $9 \mathrm{~km}$. Krebet already has more than $\mathbf{4 0}$ galleries that have a lot of craft products that were sent to various cities in Indonesia such as Yogyakarta, Jakarta, Bali, and others outside Java and it has also 10 kinds of cultural attractions. The local people are independent and take initiative in performing. They do not depend on the Head of Tourism Village. Several advantages such as a container art studio Krebet Earth for children, there is a local content of art, dance, and making wooden batik Krebet Krebet in schools (from kindergarten, elementary, junior high). To support the tourism Krebet, the community formed several groups including Natural Griya (Homestay), Tunas Aji (planting tree seedlings), Senandung Tour (Art Krebet), Various Creative (Recycled Product), Sari Natural (Culinary) and Krebet Information Center.

Three main things are important to explain here, namely, the development of the Tourism Village must be by the government policy framework, how the supply side (attractions, promotions, information, services, and transportation) is well packaged to attract the demand side and how much influence the stakeholders have in the tourism system.

Firstly, the development of the Krebet Tourism Village is following the framework of the Government of Bantul Regency in the Mid-Term Development Plan (RPJMD) of Bantul Regency in 2016 - 2021 that the determination of the strategic areas of the regency includes economic strategic areas, socio-cultural strategic areas, and environmental strategic areas. The development of Tourism Villages is included in the socio-cultural strategic area of the district including the strategic tourism village area, the Gabusan-Manding-Tembi craft (GMT) in Sewon District, and Kasongan-Jipangan-Gendeng-Lemahdadi (Kajigelem) in Kasihan 
District. The development of the Krebet Tourism Village is included in the strategic area of the Bantul regency tourism village. The emergence of a Tourism Village in Bantul Regency as an alternative tourism destination will provide destination choices for tourists visiting Bantul to improve the welfare of the local community and environmental sustainability.

Secondly, how attractions are packaged, promotions carried out, how effectively information is conveyed to market segments, how services including the facilities provided, and transportation are elements to meet the demands of tourists and buyers. Facilities and services in meeting the needs of tourists such as food and accommodation are very important to extend the stay of tourists in tourist destinations (Hudson, 1998).

Lastly, how big the role of stakeholders influencing the tourism system is. In developing tourist destination activities/activities, stakeholders need to play a role in gaining the strength of the resources offered at a destination (Ritchie \& Crouch, 1999). Starting from the local community (how to package cultural resources and natural resources, good organization and creative entrepreneurship), the role of the Bantul Regency Government (policy), and the private sector will influence the basic functions of demand and supply of the tourism system in the development of the Krebet Tourism Village so that it can bring tourists and buyers.

\section{Demand Sides: Tourist Visit the Krebet Tourism Village}

Demand sides include motivation, perception, previous experience, and expectations of tourists. Motivation arises from various socio-cultural factors. The motivation that drives someone to travel or travel is also called travel motivators. Five basic motivations encourage individuals to travel or tour (Hall, 2008) including:

1. Psychology, including the need for relaxation and improve health. For example, relaxation, spa tours and enjoy a cruise trip.

2. Culture is the desire to learn art, culture, customs, living cultures in a community.

3. Social, including trips to visit friends, relatives, businesses, and conferences.

4. Spiritual which includes pilgrimage, religious, and spiritual tourism has become a part of tourism.

5. Fantasy is one of the modern tourist experiences where tourists see images like in the real world.

In the case of the Krebet Tourism Village, the motivation that drives tourists to visit the Krebet Tourism Village is the cultural motivation (push factor). Tourists can learn art, culture, customs, social systems and community life (living culture) in the Krebet Tourism Village, namely learning to make wood batik, carving, learning the art of dancing, gamelan, learning music from the Senandung Wisata Group (Agus Jati Kumara 2019, Personal communication, 29 September). The Krebet Tourism Village also often wins the DIY Provincial level musical competition. The desire of tourists to learn to make batik on wood media, learn to dance and musical and living culture has become a driving factor for tourists visiting the Krebet Tourism Village.

Supply Sides of Krebet Tourism Village to Meet the Needs of Market Segments (Tourists) There are several main components in the supply sides, namely attractions, promotions, information, services, transportation. To meet market demand, good packaging is needed to 
attract tourists to visit (pull factor). How Krebet Tourism Village can design a destination with its attractions, promotions, services, and superior products so that the market will attract both domestic and foreign tourists with sustainability. Tourist destinations that are equipped with infrastructure, facilities, accommodation, attractions, etc., are very important to ensure a tourist destination (in this case the Krebet Tourism Village) can meet the supply and demand of tourists (Hudson, 1998).

\section{Attraction}

There are three main requirements for tourist attractions include something to see, something to do, something to buy to meet tourist satisfaction (Yoeti, 1997), namely:

1. Something to see (what is seen), tourists visit the Krebet Tourism Village to see the making of wooden handicrafts at home industries, to see the merti village ceremonies and cultural parades.

2. Something to do. Tourists can get the experience of traveling in the Krebet Tourism Village by doing activities such as learning to carve, batik wood masks, learn to color masks using paint.

3. Something to buy (what can be bought). Tourists can buy Krebet Tourism Village products such as wooden handicraft products, wooden batik masks, loro blonyo statues, various miniature animals and various functional items such as tissue boxes, trays, fruit trays, jewelry trays, and so on.

Attractions according to the Directorate General of Government (1998) are divided into three types of attractions which include natural tourism attractions, cultural tourism attractions and special interest tourism attractions. The attractions in the Krebet Tourism Village are: First, the Krebet Tourism Village natural attractions, namely the Waterfall Waterfall, Curug Jurang Pulosari surrounded by teak trees. Second, Data from (Krebet Tourism Village Manager, 2019) mentioned that Krebet Tourism Village cultural attractions namely Hadroh, Karawitan Pendopo, Ketoprak Eka Muda Putra Budaya, Jathilan Sri Mudo Budoyo, Jathilan Bekso Kudo Mataram, Sholawat Maulud Gendring, Sekar Alit Mocopat, Keprajuritan, Campursari and Jaranan Mataram Sentherewe. For the dance contained by the Motherland Studio. The Krebet community always displays cultural tourism attractions routinely once a week and is always ready at any time to display these arts. Third, special interest tourism attractions in the Krebet Tourism Village include village cruising activities, community forest or plantation tour, the home industry of wood crafts, sports, and outbound activities. The role of activities is very important in influencing the development of tourist destinations (Mathieson \& Wall, 1982).

\section{Promotion}

Promotion is conducted to communicate with tourists about the products offered and to influence tourists to buy these products. Forms of promotion carried out such as advertisement (advertising), sales promotion (sales promotion), and public relations (Kotler and Armstrong, 2014). Advertising is all forms of communication through media such as newspapers, radio, magazines, television, brochures, billboards, and so on. The advertising media used by the Krebet Tourism Village for promotion are newspapers, television, brochures, websites, banners. Sales promotions can also be done through exhibitions, and other activities that can be used to stimulate sales (Copper., et al., 1998). 
Krebet Tourism Village as a special interest tourist destination must be able to attract tourists to visit and one of the efforts made to achieve this is through tourism promotion or marketing. This concept is carried out by a destination, in this case, the Krebet Tourism Village through planning, implementing, controlling, and evaluating activities in meeting the needs and desires of tourists (Morrison in Mill and Morrison, 2009; Sunaryo, 2013: 178). The Bantul District Tourism Office includes Tourism Villages in regular exhibitions in the regencies, provinces, and publishing promotional materials. Examples of Tourism Villages include Krebet following the Travel Dialogue to Cirebon and other cities by inviting school principals, making presentations on the potential of Tourism Villages, and discussing to attract visiting markets (Karman 2019, Personal Communication, 29 September). Still according to Karman (2019) mentioned that the media also helped promote the Tourism Village including Krebet namely Tribune, Bernas, Kedaulatan Rakyat Online, Instagram Bantul Roaming. Besides, AdiTV, TVRI, TransTV Si Unyil, SCTV, RajawaliTV, Kedaulatan Rakyat's laptop program covered the Krebet Tourism Village while holding an event (Agus Jati Kumara 2019, Personal Communication, 29 September 2019). Still, according to Agus, Krebet Tourism Village also sells tour packages through websites and promotions to schools both in Yogyakarta and outside the Yogyakarta region and follows Table Top.

\section{Information}

The Krebet Tourism Village also has the Krebet Information Center (KIC). The Krebet Information Center (KIC) was formed by the Krebet community group to help provide information to tourists as well as the promotion of the Tourism Village both directly and through websites. KIC can provide information about any superior products or Krebet tour packages directly to buyers or tourists. KIC received funding from Rp. 12.5 million from 2009 Tourism PNPM used for promotional purposes such as:

1. Domain creation, hosting on websites

2. Krebet promotional leaflets 3000 pieces

3. Maps and booklets (10 pieces)

4. Neon boxes, nameplate, product display racks, admin racks, and other equipment

Website creation services with assistance from CV Karya Mandiri Primasindo (Rp. 5.6 million), namely for promotion via the internet and direct access via www.krebet.com (Fajri, 2011). To increase the promotion of the Krebet Tourism Village, the manager of the Krebet Tourism Village was also greatly helped by the existence of a Real Work Lecture (KKN) program, and direct university programs. Thus, superior products and attractions of the Krebet Tourism Village can be promoted online so that they become an attraction for tourists and buyers of wooden batik.

\section{Services}

Services include accommodation facilities for tourists and supporting facilities including food and drink services, souvenir shops, tourist information centers, banking facilities, and other comfort support facilities (Cooper, et al, 1998: 106). Krebet Tourism Village has staying facilities with 25 homestays (80 rooms) with a capacity of 300 people. Stay facilities (accommodation) Krebet Tourism Village is supported by supporting facilities including:

1. Food and beverage facilities provided by catering and food stalls include traditional types of food and drinks and culinary packages such as gudeg manggar, bacem 
tempe, cassava tape, tubers (uwi, gembili, suweng, cassava, gadung, modro), trancam and drinks such as legen and wedang tamarind.

2. Souvenir shop. Krebet Tourism Village souvenir shops are Punokawan Studio, Erlangga Wooden Batik, Saggar Rama Shinta, Estu Batik, Yuan Art, Peni Studio, and others. These shops sell wooden batik products such as wayang klitik, tissue boxes, fruit containers, loro blonyo statues, key chains, and other wooden batik products. Every month, the Krebet Tourism Village can produce 10,000-20,000 items of wooden batik handicraft products with an average turnover of handicraft 25-40 million per month (Agus Jati Kumara 2019, Personal Communication, 29 September). Besides, there are typical souvenirs of Javanese sugar and screen printing Krebet Tourism Village.

3. Toilet. Toilets are also provided both in homestays and in the homes of Krebet residents and water availability is vital in the development of Tourism Villages.

4. Pendapa Pendapa is used especially when Krebet performs routine art and cultural events. Besides, the Pendapa was also used for the Merti Dusun Krebet program, a ceremony that was held as an expression of gratitude to God for all the blessings of abundant produce. The ceremony took place with the Gunungan chanting containing staple food and was followed by the local Krebet community by carrying a festivity containing apem, sticky rice, compote, banana and flower offerings.

5. The mosque. The Krebet Tourism Village is supported by the existence of a mosque facility located $1 \mathrm{~km}$ from the Pendeb Krebet. Thus, tourists can still worship while traveling. The mosque yard is also used during the Gunungan handover during the Merti Dusun ceremony.

6. WiFi internet facilities and the Tourist Information Center. Besides being used as a promotion of the Krebet Tourism Village, the Krebet Information Center is also a tourist information center when tourists visit to find out tour package information and prices offered with affordable wifi facilities.

\section{Transportation}

Krebet Tourism Village is located approximately $12 \mathrm{~km}$ Southwest of Yogyakarta City. To reach Krebet Tourism Village, there are 2 alternative roads namely passing through Kasongan Tourism Village Road or turn right after reaching the Great Mosque of Bantul (approximately $6 \mathrm{~km}$ ). Tourists can prepare a private vehicle or contact a tour agent that provides travel services. In addition to participating in the Java Promo and trying to make a Batik Trip and Batik lunch package (input from GIPI), a travel agency that connects tourists with the Krebet Tourism Village (Agus Jati Kumara 2019, Personal Communication, 29 September 2019), namely:

1. LevelSix (Jakarta)

2. Cemerlang Travel (Bandung) dari sekolah-sekolah BPK Penabur SMP dan SMA.

3. Antasena Travel

4. Pamerta Travel

5. Elkas Tour \& Travel

6. Satu Jalan Tour

7. Ciptomas Travel

8. Royal Travel

9. Trapsona Travel

10. PT. Wira Jogja Wisata (wiratourjogja.com) 


\section{Tripilar Wisata (tripilarwisata.com) \\ 12. Labiru Tour \& Travel (paketwisatajogja.com)}

Related to tourism and the current creative economy, Desa Wisata is also required to offer its products sustainably (supply sides) so that its products remain in demand by the local, national and international markets (demand sides). To clarify the basic functions of supply and demand in the development of the Krebet Tourism Village will be explained as follows:

Table 2. Supply dan Demand in the Development of Krebet Tourism Village

\begin{tabular}{|c|c|c|c|c|}
\hline Attraction & Promotion & Information & Services & Transportation \\
\hline $\begin{array}{l}\text { Natural Attraction: } \\
\text { 1. Curug Pulosari } \\
\text { Waterfall } \\
\text { Cultural Attraction: } \\
\text { 1. Traditional } \\
\text { Dance } \\
\text { 2. Hadroh } \\
\text { 3. Karawitan } \\
\text { 4. Ketoprak } \\
\text { 5. Jathilan } \\
\text { 6. Sholawat } \\
\text { 7. Mocopat } \\
\text { 8. Keprajuritan } \\
\text { 9. Campursari } \\
\text { 10. Jaranan } \\
\text { Special Interest } \\
\text { Attraction: } \\
\text { 1. Environmental } \\
\text { Education Tour. } \\
\text { 2. Adventure and } \\
\text { Outdoor } \\
\text { 3ctivities. } \\
\text { 3. Wooden Craft } \\
\text { 4ome industry } \\
\text { 4. Outbond }\end{array}$ & $\begin{array}{l}\text { Advertisement } \\
\text { dan public } \\
\text { relations through } \\
\text { newspaper, } \\
\text { brochure, } \\
\text { television/ } \\
\text { media: } \\
\text { 1. Tribun } \\
\text { 2. Bernas } \\
\text { 3. Kedaulatan } \\
\text { Rakyat } \\
\text { Online } \\
\text { 4. Instagram } \\
\text { Jelajah } \\
\text { Bantul } \\
\text { 5. AdiTV } \\
\text { 6. TVRI } \\
\text { 7. TransTV } \\
\text { acara laptop } \\
\text { Si Unyil } \\
\text { 8. SCTV } \\
\text { 9. RajawaliTV } \\
\text { 10. Kedaulatan } \\
\text { Rakyat } \\
\text { Websites: } \\
\text { www.krebet.com } \\
\text { Exhibition: } \\
\text { Travel Dialogue } \\
\text { Table Top } \\
\text { Etc. }\end{array}$ & $\begin{array}{l}\text { Krebet } \\
\text { Information } \\
\text { Center }(\mathrm{KIC}) \text {. }\end{array}$ & $\begin{array}{l}\text { 1. Accommodation: } \\
\text { Homestay } \\
\text { 2. Restaurant } \\
\text { 3. Souvenir Shop } \\
\text { and Handicraft } \\
\text { Workshop. } \\
\text { 4. Toilet } \\
\text { 5. Pendapa } \\
\text { 6. Mosque } \\
\text { 7. Wifiand Tourism } \\
\text { Information } \\
\text { Center. }\end{array}$ & $\begin{array}{l}\text { Private transportation and } \\
\text { travel agent: } \\
\text { 1. LevelSix (Jakarta) } \\
\text { 2. } \text { Cemerlang Travel } \\
\text { (Bandung) } \\
\text { 3. Antasena Travel } \\
\text { 4. } \text { Pamerta Travel } \\
\text { 5. Elkas Tour \& Travel } \\
\text { 6. Satu Jalan Tour } \\
\text { 7. Ciptomas Travel } \\
\text { 8. } \text { Royal Travel } \\
\text { 9. Trapsona Travel } \\
\text { 10. PT. Wira Jogja Wisata } \\
\text { (wiratourjogja.com) } \\
\text { 11. Tripilar Wisata } \\
\text { (tripilarwisata.com) } \\
\text { 12. Labiru Tour \& Travel } \\
\text { (paketwisatajogja.com } \\
\text { ) }\end{array}$ \\
\hline
\end{tabular}

Source: Adaptation from Hall (2008)

Based on Table 2 above, to satisfy market demand (demand), the Krebet Tourism Village must be able to provide services and a variety of development (supply). The basic function of supply-demand from the tourism system above is also influenced by external factors, namely natural resources, cultural resources, government policy, competition, community, community, entrepreneurship (entrepreneurship), labor (labor), finance (finance) and organization/leadership (organization/leadership) which will be explained as follows: 
1. Natural Resources

Natural resource assets or natural tourism potential are considered as important factors that influence the development of tourism and are one of the destinations of tourists coming to tourist destinations. There are five aspects of natural resources as a tourist attraction namely water, topography, vegetation, wildlife, and climate (Gunn, 2002: 60). Krebet's natural resources are water, which is the waterfall which is a seasonal waterfall in the Pulosari waterfall, which is often used for photography; and vegetation, namely the Krebet region, which is surrounded by a variety of plants, especially the sengon and teak trees, which are often used for village cruising, community forest tourism, and plantations. Sengon trees and teak trees are also raw materials used by the community to produce wooden batik crafts. To maintain the sustainability of this vegetation, local people continue to strive to replant sengon seedlings and teak trees.

2. Cultural Resources

Cultural resources can be used as a tourist attraction that includes cultural values and customs (cultural heritage). In addition to having superior wood batik handicraft products, the Krebet Tourism Village continues to preserve the art and cultural resources through the Senandung Wisata groups, which focus on the development of Krebet arts and theater and working on artistic equipment. Local people in the Krebet Tourism Village routinely carry out the Merti Dusun Ceremony and Nyadran Makam Sewu Ceremony. Sanggar Pertiwi as a place for children and young people to practice Javanese dancing and preserve Krebet culture. In schools (TK Masyitoh, SD Krebet, SMPN 3 Pajangan) in the Krebet area there is also local content of art, dance, and batik making of Krebet wood (Fajri, 2011).

3. Government Policy

Government policies have a strong influence on the growth of the tourism sector. What is meant here is a policy issued by the government both central and local that can affect the development of tourism. Central government policy in favor of Micro, Small, Medium Enterprises and Cooperatives (UMKM) Article 17 of the Tourism Law (UUK), the Government and Regional Governments must develop and protect micro, small and medium businesses and cooperatives in the tourism business by:

a. Make a policy of backing up tourism businesses in micro, small and medium enterprises, and cooperatives.

b. Facilitating micro, small, and medium business partnerships and cooperatives with large scale businesses.

The point is that every actor in tourism is obliged to develop partnerships with local small businesses and cooperatives with mutual need, strength, and benefit. Article 61 of the Undang - Undang Keistimewaan (UUK) also states that the Government and Regional Governments provide funding opportunities for small businesses in the tourism sector. One of the efforts of the DIY Tourism Office is to hold a Village Competition/ Tourism Village in the Province of DIY to motivate the Tourism Village to progress in its management and be able to develop its potential. Besides, the Yogyakarta Provincial Tourism Office is a facilitator who provides training, and marketing, especially in improving community human resources in the Tourism Village. In the Krebet case, the facilitation effort was carried out by the Culture and Tourism Office and the Bantul Regency Trade, Industry, and Cooperative Office (Disperindagkop) to the local community. The facilitation can be done by providing funding 
opportunities (mentioned in article 26 of the UUK) for small businesses such as craftsmen for example. In addition to the 'umbrella' in the form of regulations, the Office also made the following efforts (Karman 2019, Personal Communication, 29 September):

1. Capital.

The Dinas facilitates small businesses for promotion by attending exhibitions. In the Krebet Tourism Village at least the exhibition is held once a month and participants consist of groups of craftsmen who take part in turn such as the Inacraft exhibition at the Jakarta Convention Center, Jogja Expo Center, Batik Title, Furnicraft held in Yogyakarta, Jakarta, and Bali where exhibition stands have been provided by the Department of Tourism or Disperindagkop Bantul.

2. Coaching.

Training and development of community resources by holding awareness about tourism awareness understanding (Pokdarwis), design training, Sapta Enchantment including product packaging. In this regard, the Bantul Regency Tourism Office seeks to develop the human resources of the Tourism Village community through joint training with Pokdarwis Krebet.

4. Marketing.

Krebet Tourism Village product marketing has taken advantage of the internet (through websites), although it is still incorporated in the Bantul District Tourism Office subdomain. Bantul Regency Tourism Office also seeks to grow community small businesses for the development of the Krebet Tourism Village through training (human resource development, homestay training, comparative studies to other Tourism Villages), marketing (creating websites, e-commerce selling online) and promotion (exhibition and manufacture of leaflets).

4. Competition

The Krebet Tour Package includes: art learning tours, art learning tours, homestay tours at residents' homes, culinary tours, village, and home industry tours, tradition tours, sports and outbound tours, and traditional game tours. These ten types of attractions emphasize the experience and education that tourists are most interested in getting experiences. The active role of the community can be seen from their involvement in the Association of Krebet Craftsmen, Pokdarwis, and Sido Katon Cooperative. The purpose of establishing P2K is to unite the craftsmen, especially related to the need for equipment and proposals to the relevant Dinas, and help the craftsmen to provide recommendations to be trusted in applying for capital loans to banks, for example to Mandiri and BTN. Pokdarwis is a community forum that focuses on tourism development in the Krebet Tourism Village which is divided into six groups, namely: the Griya Alami Group (homestay), the Tunas Aji Group (handicraft raw material), the Humming Tourism Group (arts and theater), the Various Creative Groups (innovation product), Sari Natural Group (culinary) and Krebet Information Center (information and promotion center). Sido Katon Cooperative was established at the P2K initiative, which was fostered by Disperindagkop, Bantul Regency. The purpose of the Sido Katon Cooperative was to help resell semi-finished products from craftsmen and provide the need for supporting materials for wooden batik crafts such as dyes, wax, sandpaper, magnets, glue, packing material, and others. 


\section{Community}

By developing tourism activities in the local community environment, there will also be changes in the living system in it (economy, culture, environment, etc.). The development of the Tourism Village has to help improve the economic and social conditions of the surrounding community. The active role of the Krebet community at large is very important especially in the effort to develop the Tourism Village. In the 1980 s the craft was originally only carried out by Krebet residents. However, along with the development of the craft era, it is done outside the Pajangan subdistrict. The development of the Krebet Tourism Village aims to reduce poverty by empowering local communities and absorbing the workforce in Krebet and outside Krebet so that the community can be directly involved and benefit. In general, the main livelihoods of the people in the Krebet Hamlet are farmers, but now many are turning to craftsmen because they are more profitable. At present, the number of studios in Krebet has grown to have 57 wooden batik workshops.

The active role of the community can be seen from their involvement in the Association of Krebet Craftsmen, Pokdarwis, and Sido Katon Cooperative. The purpose of establishing P2K is to unite the craftsmen, especially related to the need for equipment and proposals to the relevant Dinas, and help the craftsmen to provide recommendations to be trusted in applying for capital loans to banks, for example to Mandiri and BTN. Pokdarwis is a community forum that focuses on tourism development in the Krebet Tourism Village which is divided into six groups, namely: the Griya Alami Group (homestay), the Tunas Aji Group (handicraft raw material), the Humming Tourism Group (arts and theater), the Various Creative Groups (innovation product), Sari Natural Group (culinary) and Krebet Information Center (information and promotion center). Sido Katon Cooperative was established at the P2K initiative, which was fostered by Disperindagkop, Bantul Regency. The purpose of the Sido Katon Cooperative was to help resell semi-finished products from craftsmen and provide the need for supporting materials for wooden batik crafts such as dyes, wax, sandpaper, magnets, glue, packing material, and others.

6. Entrepreneurship

In developing tourism, entrepreneurs are needed to develop and create opportunities in development. The local people of Krebet Tourism Village already have high creativity and can capture market opportunities. This is certainly also inseparable from the role of the Bantul Regency Office of Industry and Trade who continues to stimulate creativity, especially craftsmen through the National Crafts Council or Dekranas (Fajri, 2011).

7. Labor

The availability of skilled and educated human resources in tourism development locations also plays an important role because the higher the level of demand, the greater the trained, educated human resources needed. Most of the main livelihoods of the people in the Krebet Hamlet are farmers, but now many are turning into craftsmen. The demand for Krebet products and tourist visits has continued to increase from year to year. Krebet craftsmen can produce 10,000-20,000 wooden batik items per month and many Krebet craftsmen and groups can sell online to meet market demand. That is why Krebet's superior products can be hit on the international market. The APIKRI Non-Governmental Organization helps direct the craftsmen in designing the product according to the buyer's request. These 
craftsmen are formed in the Krebet Craftsmen Association (P2K) group who often take part in exhibitions in Yogyakarta, Jakarta and Bali routinely rotate to gain new insights in innovation.

Table 3. The Names of the Wooden Batik Craft Owners in the Krebet Tourism Village

\begin{tabular}{llll}
\hline Sanggar Punokawan & Dewi Sri & Teratai & Batik 99 \\
Ragil Handycraft & Prima Batik & Sido Dadi & Bayu Aji \\
Sari Mekar & Pendopo & Mifta Handycraft & Hasta Karya \\
Joko Tingkir & Tio Batik & Hasta Aji & Kinanthi Bubut \\
Batik Sekar Melati & Devia Art & Bayu Aji & Mayza Art \\
Akbar Jaya & Kajeng Muni & Nakula & Roto Craft \\
Wisma Kreasi & Bagong Handycraft & Yuan Art & Sanggar Peni \\
Karya Mandiri & Tamarine Craft & Batik Tyas & Sanggar Arjuna \\
Widoro Kandang & Salsa Mebel & Linggar Jati & Yanto Batik \\
Sri Rejeki & Karya Mandiri Utama & Aditya Batik & Nakulo Sadewa \\
\hline
\end{tabular}

Source: Krebet Tourism Village, 2019

\section{Finance}

Funding is an important thing that is needed in the development of tourism. Funding can come from various parties, namely the government, private sector/investors as well as from the local community. The Ministry of Tourism through PNPM Mandiri Tourism in 2009 provided funds for homestay development, tour guide training, comparative studies to other Tourism Villages, KIC promotion needs (making websites, leaflets, maps, booklets, neon boxes, etc.) and to purchase equipment traditional music such as gongs, kenting, drums, costumes, pants, and fingers. The 2010 PNPM Mandiri Tourism Fund provided funds for the development of the arts to meet the needs of attractions such as entertainment, costumes, and art equipment. The bank provides revolving funds for small businesses to develop the Krebet Tourism Village. The local Krebet community manages its finances together by making regular contributions to the Sido Katon Cooperative (Fajri, 2011).

9. Organization

The organization is an external factor that has an important role in tourism planning and development. Organizations that play an important role in the development of the Krebet Tourism Village are with Academics, the Krebet Tourism Village has an MoU with Universities, namely with PUSPAR UGM, UMY, Sanata Dharma, Atmajaya, ISI which is more for consultation/preparation of tourism planning (Karman 2019, Personal Communication, September 29).

\section{Conclusion}

In developing a destination there is a tourism system that must be built. The tourism system plays an important role in developing tourist-friendly tourist destinations so that tourists can get an optimal experience. In this case, the Krebet Tourism Village can develop sustainably without being separated from how its tourism system. The Gunn Model in the Tourism System - supply and demand can analyze in detail how the tourism system develops the Krebet Tourism Village. The basic function of supply-demand development in the Krebet Tourism Village is also influenced by external factors, namely cultural resources, natural resources, government policy, competition, community, community, entrepreneurship (entrepreneurship), labor (labor), finance (finance) and organization/ leadership 
(organization/ leadership). The development of the Krebet Tourism Village can be a good reference for the development of other Tourism Villages such as Bobung, not only to improve the welfare of the community, it is important to play an important role in ensuring a tourist destination, in this case, the Krebet Tourism Village, can meet supply sides and demand sides) tourists.

\section{References}

Anuar, A., Ahmad Habibah., Jusoh Hamzah., Hussain M. (2012). The Roles of Tourism System Towards Development of Tourist Friendly Destination Concept. Asian Social Science, Vol. 8, No.6, p.146-155. www.ccsenet.org/ass

Baiquni, M. (2006). "Pengelolaan Sumber Daya Perdesaan dan Strategi Penghidupan Rumah Tangga di DIY Masa Krisis (1998-2003)". Disertation. UGM, Yogyakarta.

Cooper, C., John Fletcher, David Gilbert, Rebecca Shepperd \& Stephen Wanhill. (1998). Tourism Principles and Practice. Singapore: Pearson Education Asia Pte Ltd.

Desmond. (1999). Staging Tourism: Bodies on Display from Waikiki to Sea World. Chicago: University of Chicago Press.

Direktorat Jenderal Pariwisata, Depparsenibud RI. (1998). Rencana Induk Pengembangan Pariwisata Nasional 1998 Laporan Akhir Nomor 1.

Fajri, D. N. A. (2011). Pariwisata Indonesia dalam Menghadapi Peluang di Era Globalisasi (Studi Kasus: Desa Wisata Krebet, Kecamatan Pajangan, Kabupaten Bantul, Provinsi DIY). Tesis. Universitas Gadjah Mada.

Gottdiener. (2000). New Forms of Consumption: Consumer, Culture, and Commodification. New York: Rowman and Littlefield.

Gunn, C. A \& Var, Turgut. (2002). Tourism Planning: Basics, Concepts, Cases, $4^{\text {th }}$ Edition. New York: Routledge.

Hudson, B.J. (1998). Waterfalls, Resources for Tourism. Annals of Tourism Research, Vol. 25, No. 4, 958-973. http://dx.doi.org/10.1016/S0160-7383(98)00043-7.

Jawardena. (2002). Mastering Carribien Tourism. International Journal of Contemporary Hospitality Management. Vol. 14, No. 2, 88-93. http://dx.doi.org/10/1108/09596110210419273.

Mason, P. (2003). Tourism Impact, Planning, and Management. Oxford: ButterworthHeinemann.

Mathieson, A., \& Wall, G. (1982). Tourism: Economic, Physical, and Social Impacts. Harlow: Longman.

Mill, R.C., \& Alastair, M. (2009). The Tourism System 6 th Edition. USA: Kendall Hunt Publishing Company.

Kotler, P., and Armstrong, G. (2014). Principles of Marketing 15th Edition. England: Pearson Education Limited.

Peraturan Daerah Kabupaten Bantul Nomor 18 Tahun 2015 Tentang Rencana Induk Pembangunan Kepariwisataan Daerah Tahun 2015 - 2025. Accessed from https://pariwisata.bantulkab.go.id/filestorage/dokumen/2018/09/RIPARDA.pdf accessed on 6 Oktober 2019

Purbasari, N., and Manaf, A. (2017). Karakteristik Elemen Sistem Pariwisata Ekowisata Desa Wisata Nglanggeran dan Wisata Desa Pada Desa Wisata Pentingsari. Jurnal Pembangunan Wilayah dan Kota, Vol. 13, No.1, p. 100-113. 
Rencana Pembangunan Jangka Mengengah Daerah (RPJMD) Kabupaten Bantul Tahun 20162021. Accessed from: https://bappeda.bantulkab.go.id/data/hal/0/1/9/56-rpjmdkabupaten-bantul-tahun-2016-2021 Accessed on 6 Oktober 2019.

Rindrasih, E. (2015). Menilik Pengembangan Desa Wisata di Taman Nasional. Membangun Pariwisata dari Bawah: Catatan Penelitian terhadap Desa Wisata Penerima PNPM Mandiri Pariwisata. Yogyakarta: Gadjah Mada University Press.

Ritchie, J.R.B., \& Crouch, G.I. (1991). Tourism, Competitiveness, and Social Prosperity. Journal of Business Research, 44, 137-152. http://dx.doi.org/10.1016/S01482963(97)00196-3.

Rojek, C., \& Urry, J. (1997). Touring Cultures: Transformations of Travel and Theory. London and New York: Routledge. http://dx.doi.org/10.4324/9780203427736

Spillane, R.G. (1996). Anatomi Pariwisata Memahami Pariwisata sebagai Sistem Linkage. Jakarta: PT Gramedia Pustaka.

Sunaryo, Bambang. (2013). Kebijkan Pembangunan Destinasi Pariwisata Konsep dan Aplikasinya di Indonesia. Yogyakarta: Gava Media.

Urry, J. (2002). The Tourist Gaze $2^{\text {nd }}$ Edition. London: Sage.

Yoeti, O. A. (1997). Perencanaan dan Pengembangan Pariwisata. Jakarta: PT. Prandnya Paramita. 